\title{
THE SUCCESSIVE CRISES IN YEMEN AND THEIR IMPACT ON MICRO, SMALL AND MEDIUM ENTERPRISES(MSMES) SECTOR
}

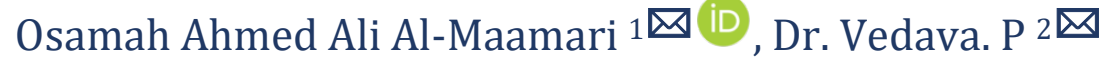 \\ ${ }^{1}$ Research Scholar, Department of Commerce Mangalore University, India \\ ${ }^{2}$ Associate Professor Department of Commerce Mangalore University, India
}

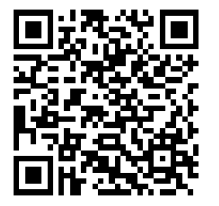

DOI: https://doi.org/10.29121/granthaalayah.v8.i12.2020.2519

Article Type: Research Article

Article Citation: Osamah Ahmed Ali Al-Maamari, and Dr. Vedava. P. (2020). THE SUCCESSIVE CRISES IN YEMEN AND THEIR IMPACT ON MICRO, SMALL AND MEDIUM ENTERPRISES(MSMES) SECTOR. International Journal of Research GRANTHAALAYAH, 8(12), 5-14. https://doi.org/10.29121/granthaa layah.v8.i12.2020.2519

Received Date: 23 November 2020

Accepted Date: 21 December 2020

Keywords:

Micro, Small and Medium

Enterprises $\left(\mathrm{MSME}_{\mathrm{s}}\right)$

Conflict

Crisis

Challenges

\begin{abstract}
This study aimed to highlight the challenges and difficulties that face micro small and medium enterprises MSMEs on inhibiting from contributing to developing the Yemies economy and to know the impact of the successive crises and conflict on MSMEs. Through a review of the literature and previous studies in this regard, it was possible to summarize the most critical problems facing MSMEs in Yemen, which could be difficulties like getting funds, poor infrastructure, corruption, difficulties in securing raw materials, lack of skilled employees, and also difficulties to get Licensing and the absence of a specific SMEs authority.
\end{abstract}

\section{INTRODUCTION}

\subsection{ROLE OF MICRO, SMALL AND MEDIUM ENTERPRISES(MSMES) IN THE ECONOMY}

Small and medium enterprises have contributions to the economy that regarding different Economists which discusses the impact of MSMEs on the economy of any country. Some Economists argue that small and medium enterprises have an essential role in any economy because it has an essential role in decreasing the unemployment rate, economic growth, and innovation. Simultaneously, other Economists argue that large enterprises have more effect on the economy than MSMEs in producing the desired economic growth and development levels. According to David Audretsch, it is necessary to get a closer look at the role of MSMEs on economic growth with his opinion he shows that the increase in employment rate in the USA during the 1990 s was $17.76 \%$ that's because of the net growth in employment in MSMs; also, in the same time, there is a decrease in employment in large enterprises within the same period. He also said that the USA economy's growth during the 1980s and 90s was because the MSMs as improved competition, served as an agent of change (innovation), and contributed to employment.

(C) 2020 The Author(s). This is an open access article distributed under the terms of the Creative Commons Attribution License, which permits unrestricted use, distribution, and reproduction in any medium, provided the original author and source are credited. 
There is growing recognition of the critical role of micro, small, and medium enterprises (MSMEs) in the last several years because it's an essential role in economic development. Their role also contributes to solving the unemployment problem. On the other hand, supporting MSMEs helps empower young people to do successful work. As small projects, those who have distinct ideas are the appropriate work for those who have a sense of creativity, innovation, and development. Therefore, the government should create an appropriate environment and prevent monopoly (large enterprises' monopoly on market and resources).

One of the advantages of MSMEs is that they do not require large capital, which is easy to establish. Anyone intends to establish his own business to develop a thoughtful plan for his project, as the desire to establish a project without prior study will fail. To establish a successful project, the market must be studied, and competitors must be studied as well. Also, pricing is one of the essential features of the project (goods or services) from others and determines the demand. So, pricing has steps that must be adhered to so that the beginner can compete in the market.

The MSMEs constitute about 99.49\% of Yemen's total business units (The YMIT 2014 (Where; many economists consider small enterprises as one of the most critical sectors in any economy because of their significant role in reducing unemployment rates and the growth of the economy and raising the level of production as well as in innovation as well as as the basis for large projects

The growth and development of the micro, small and medium enterprises sector in all parts of the world face many problems. These may be different from one country to another and from one industry to another. Still, some issues are considered unified or recognized problems are facing MSMEs all over the world. The nature of the difficulties encountered by MSMEs is intertwined with each other. In general, part of these problems is internal, which are the problems that occur within the enterprise or its owner. Simultaneously, there are considered external problems if they occur due to the action and influence of external factors or the environment surrounding these facilities.

At the same time, the micro, small and medium enterprises sector in Yemen suffer from many problems and obstacles despite its essential position on the map of development plans in the country as one of the main pillars in developing economic life and its role in the growth of national income and contributing to meeting the needs of society, by providing opportunities for people to get Work and also the productivity. The main problem facing the MSMEs sector in Yemen was the violent conflict (war), which will be affected in the economy in general

\subsection{A BRIEF DESCRIPTION OF THE SITUATION IN YEMEN}

Yemen is one of the poorest and least developed countries in the world with a GDP of 27.59 billion U.S. dollars in 2018 (according to official data from the World Bank and projections from Trading Economics), and ranking 175 among 191 of the poorest countries and regions in the world (International Monetary Fund, World Economic Outlook October 2019). Combined with high annual population growth (2.7 percent) (The World Factbook), and a low adult literacy rate (only 50.2 percent in total and 30 percent among women), Yemen has a high unemployment rate (estimated at 35 percent) (Kirchhoff 2000). These negative figures were caused by many factors, perhaps the most prominent of the political problems since 2011 and the war that has existed since 2015 until now, and many other issues causing the low level of the Yemeni economy's rising unemployment rates. Because of those problems, the sector of micro, small, and medium enterprises in Yemen suffers from many problems and obstacles; one of the biggest problems facing MSMEs was that the financing problem is the most critical obstacle preventing MSMEs' development establishments in Yemen.

Table1: Yemen GDP Growth Rate

\begin{tabular}{|l|l|l|}
\hline Year & GDP Growth (\%) & Annual Change \\
\hline 2010 & $7.70 \%$ & $3.84 \%$ \\
\hline 2011 & $-12.71 \%$ & $-20.42 \%$ \\
\hline 2012 & $2.39 \%$ & $15.11 \%$ \\
\hline 2013 & $4.82 \%$ & $2.43 \%$ \\
\hline 2014 & $-0.19 \%$ & $-5.01 \%$ \\
\hline 2015 & $-27.99 \%$ & $-27.81 \%$ \\
\hline 2016 & $-9.38 \%$ & $18.62 \%$ \\
\hline 2017 & $-5.07 \%$ & $4.30 \%$ \\
\hline
\end{tabular}


Osamah Ahmed Ali Al-Maamari, and Dr. Vedava. P

\author{
Source: Macrotrends.net
}

\begin{tabular}{l|l|l}
2018 & $0.75 \%$ & $5.82 \%$ \\
\hline
\end{tabular}

\title{
1.3. THE PROBLEM OF THE STUDY
}

Micro, Small and Medium enterprises have great importance for the economy of any country, as they work to revitalize the economy, reduce unemployment rates, raise production efficiency and others. Still, in recent years the MSMEs sector in Yemen has lived a challenging period due to the current political conditions and the successive crises that affected the growth of small enterprises and caused the deterioration of this capacity. The sector is based on the growth of the Yemeni economy and also raising employment rates. Therefore, in this article, we will discuss the most critical problems and challenges facing the MSMEs sector due to the successive crises that have afflicted Yemen since 2011 until now.

\subsection{THE OBJECTIVE OF THE STUDY}

The main objective of this study is to know the challenges and difficulties facing micro, small, and medium enterprises in Yemen. To be more specific, this study aims to describe the impact of Yemen's political issues since 2011 and the conflict since 2015 on the performance of MSMEs.

\subsection{REVIEW OF LITERATURE}

Aliriani (2012) Conducted a study to describe the role of the micro, small, and medium enterprise (MSME) sector in the Yemeni economy. And the researcher explains how MSME can play an essential role in creating jobs for people looking for the opportunity. And also shows that the MSMEs sector in Yemen is facing many challenges and difficulties in growth like inadequate infrastructure, difficulties in obtaining raw materials, lack of technological support, difficulties in identifying and implementing new technology, the lack of skilled staff, and the lack of financing opportunities. Also, they suffer from unreasonable licensing requirements by bureaucratic and non-transparent government departments, over-taxation, and much more. (Alshebami \& Khandare, 2014) reported several challenges and obstacles limiting the growth and development of small industries in Yemen, i.e., Skills and skills Acquisition, Marketing limitation, Associations and unity, Ownership of women for SMEs, the attitude of youth to work SMEs and finally High-interest rate and collateral demanded by the Microfinance institutions. (Alshebami \& Khandare, 2015) revealed that due to imposing an interest rate ceiling on low individuals who want to start their small enterprises, most of the MFIs that support the low individuals left the market or reduced their scale due to the inability to continue operating with low-interest rates indigent clients without access to credit. Peci et al. (2012) studied the impact of formal and informal factors on the growth of small and medium enterprises (SMEs) in Kosovo as a transition country. The main obstacles facing SMEs are when Kosovo engaged in international trade and knew its effect on small and medium enterprises. The researchers found that the low levels of professionalism and ethics of officials as informal activities in respective institutions and Weak laws and legislation can be effective on rising transaction costs, which can be a great obstacle to small and medium enterprises' growth. According to (Alhammadi and Shahadan,2014) the small enterprises is the main player in the job creation and employment in the worldwide in both developing and developed countries and the researchers say that small enterprises facing many challenges and difficulties in their growth performance one of this challenges is to get finance to run the business and that could be difficulties to get a loan from the financial institutions that could be because the difficult requirements to get credit and the other challenges facing small enterprises are that lack of managerial experience and other problems facing small business. They found that management capabilities determinants and business environment determinants can impact the performance and growth of small business in Yemen. (GICHUKI et al.,2014) Describe the role of micro and small enterprises in the Kenyan economy. The micro and small enterprises' role could be in job creation when the micro and small enterprises sector in Kenya create $50 \%$ of new jobs yearly to explain this sector's importance in any economy. Still, the micro and small enterprises sector faces many problems in accessing credit facilities in KangemiHarambee Market in NairobiCityCounty, Kenya. They found that the main problem facing the micro and small enterprises sector was the high-interest rate, difficult collateral, the unwillingness of people to act as guarantors, and also high credit facilities' processing fees and short repayment period; all of those could be 
challenges for micro and small enterprises sector in Kenya to accessing to the financial institutions and getting fund. According to (Avevor 2016), Small and medium enterprises are the spine of any economy globally, and most large companies were SMEs in the past. The impact of small and medium enterprises in Ghana's economy is still facing many challenges and difficulties when accessing financial institutions' funds because of the difficult requirement to get funds. The researcher found that financial institutions consider small and medium enterprises a risky sector, thereby offering them credit facilities at a high-interest rate compared to large enterprises. Al-Absi(2016) tried to know the impact of microcredit in microfinance institutions on small business in Yemen and how the services provided by microfinance institutions such as (collaterals, loan amount, loan duration, loan repayment, and interest rate) can be effected on the Performance of small business spread in Yemen. This study shows that the services provided by microfinance banks have a significant positive correlation with small businesses, and it also found that the most services of microfinance institutions can be affected by small companies was loan repayment after that was loan duration, interest rates, and loan amount respectively. (Mandal,2007) Describe how Small and Medium Enterprises (SMEs) have an important role in any country's growth. Still, the researcher observes that Small and Medium Enterprises (SMEs) have an uneven development in recent times. However, the small and medium enterprises sector in the developed countries greatly contributes to the economy and the countries' growth. On the other hand, the SME sector in developing countries has not fared well. The failure of the developing countries to take the SME sector development initiative in the right direction has been the major reason for this sector's slow process. According to (Ilahi,2015) The Micro, Small, and Medium Enterprises (MSMEs) are the primary factor in accelerating economic and social development and play an important role in the economic growth in any country. This role could be production, employment, and exports. in the last few years, The Micro, Small, and Medium Enterprises sector has consistently recorded a higher growth rate than the overall industrial sector. And the researcher found that Delhi has come out as one of the biggest centers of MSMEs in India in the last years. The focal point of this study was that the problems and prospects of MSMEs in Delhi. Though the MSMEs are still facing many problems like getting funds from financial institutions, technology problems, infrastructure, marketing, labour, etc. (Saleh and Manjunath,2020), Amid to highlight the challenges and difficulties that face small and medium enterprises SMEs on inhibiting from contributing to developing the Yemies economy. The researcher classified the challenges and difficulties into two groups the first group concerned with the historical challenges that had been facing small and medium enterprises for a long time, and the second group concerned with new challenges that appear in the last several years with the emergence of the violent conflict and political instability which can be impacted on the performance of small and medium enterprises in Yemen. (Alshebami, Al-jubari, Alyoussef, \& Raza, 2020b) confirms that there is a need to provide those people interested in starting their small businesses with the necessary education and entrepreneurial skills. It is proved that entrepreneurship education plays a significant role in changing people's attitudes toward entrepreneurship and its activities. (Alshebami, 2017) The SMEs can play a vital role in job creation and employment in the Arab world if an effort is put together to increase opportunities in the field of development and diversification of the productive base for these projects

\subsection{MICRO, SMALL, AND MEDIUM ENTERPRISES}

Many definitions dealt with the concept of micro, small, and medium enterprises. They differed between organizations and countries; some look at it from the point of the number of employees. Another view is in terms of the size of capital, and there is t a third party looks at MSMEs from the perspective of the use of technology. A study of the organization International Labor indicated that they found 75 definitions within 50 industrialized and developing countries. If consider the number of workers as a criterion for distinguishing between micro, small and medium enterprises, we find that there is no agreement on a specific number as a basis for determining the size of MSEs, as this varies according to the degree of industrial progress, which in turn differs from one country to another.

In Yemen, although there is still no specific legislation in which to distinguish micro, small, and medium enterprises from large enterprises, any of the following sources can be guided:

The final report of the results of the baseline survey of micro and small establishments for the year 2000, which defined micro and small enterprises as any income-generating activity in the field of industry, trade, or services (excluding primary industries) that employs 50 workers and markets at least $50 \%$ of its products (or services). According to this definition, enterprises with primary - traditional activities and enterprises that are established for consumption are excluded. 
The National Strategy for the Development of micro and small enterprises; which defined small enterprises as:

"any income-generating activity in the field of industry, trade, or services." It should be noted that the ministry of industry and trade distinguish between micro, small, and medium enterprises as follows:

Micro enterprises are those that employ 1-5, and the capital investment is 1 million YER.

Small enterprises are those that employ 6-15 and the capital investment from 1 million YER to 20 million YER. Medium enterprises are those that employ 15-50 and the capital investment from 20 million YER to 1 Billon YER.

This criterion is chosen for us to distinguish between micro, small, and medium enterprises in this research.

\subsection{THE OBSTACLES AND PROBLEMS FACING MSMEs}

Many micro, small and medium enterprises face several challenges that stand as a stumbling block in front of them to achieving their economic and social goals. The nature of these challenges varies according to the heart of the project, the activity it exercises, and the country in which it operates. The novelty of small enterprises' concept is one of the difficulties facing this type of enterprise, especially in the Arab countries (El-Hawat, 2007). MSMEs face many obstacles, especially about obtaining capital and the lack of adequate distribution channels (Prasad \& Tata, 2009).

The United Nations declared that the year 2005 is the year of financing small projects to provide the necessary financing for more than 20 million families in developing countries (Prasad \& Tata, 2009). One of the main obstacles for small enterprises is funding from others, where it isn't easy to rely on self-financing. The high cost of financing compared to the rate of return on the project, which in most cases leads to loss or stoppage of the project (El-Beltagy, 2005). Many studies indicate that the owners of new projects suffer from insufficient financing, lousy product, and ineffective marketing (O'Dwyer, \& Ryan, 2000) and that the local consumer preference for similar foreign products is motivated by imitation, and the lack of sufficient incentives for local products to strengthen their competitiveness compared to the foreign work and the pursuit of dumping policy by some foreign institutions greatly weakens the ability of the domestic product to compete.

We must not overlook inflation, which is a significant reason for the rise in the prices of raw materials and workers' wages, and consequently the high operating costs of this type of project, which leads to higher prices for its products, which means its inability to face intense competition from large enterprises (Qandah, 2009) as well as the governmental measures are considered the high tax rates on these projects are among the main obstacles to the development of this sector.

These projects generally suffer from their inability to provide financial data (financial statements). In China, the lack of information was one of the main reasons that led to the failure of small enterprises (Alattar, Kouly \& Innes, 2009). (1998, Lybaert) found that there is a positive relationship between the extent to which available information is used and small projects' performance. In addition to the inconsistency of information available between financial institutions and small enterprises, access to the required financing is one of the main obstacles for small and micro companies (Gebru, 2009). In a study (Gebru, 2009), it was found that the lack of adequate guarantees that could cover the value of the required loan, which is one of the main grounds for banks to agree to grant the loan, which created a significant problem for small enterprises that do not have sufficient fixed assets, especially at the beginning of their working life. About these projects, the banks depend on the establishment's capital and not on the income of the establishment to make the credit decision to grant or reject the loan.

\subsection{CHALLENGES AND DIFFICULTIES FACING MSMES IN YEMEN}

Micro, small and medium enterprises sector in Yemen suffer from many problems and obstacles despite its essential position on the map of development plans in the country as one of the main pillars in developing economic life and its role in the growth of national income and contributing to meeting the needs of society, by providing opportunities for people to get Work and also the productivity. The main problem facing the MSMEs sector in Yemen was the violent conflict (war), which will be affected in the economy in general Which in turn led to high inflation rates in the country, which will be affected by the rise in the prices of raw materials and the cost of labor, which will inevitably lead to higher operating costs. Here, these establishments face a significant problem: their confrontation with competition from large projects, which prevents them and limits their ability to raise prices to avoid high labor 
The Successive Crises in Yemen And Their Impact on Micro, Small and Medium Enterprises (Msmes) Sector

wages and raw material prices. And directly that will be reflected in the cost of capital, which is one of the biggest problems facing MSMEs because it is directly reflected in these projects' profitability through the demand from MSMEs to pay a high-interest rate compared to the price paid by large enterprises. Also, MSMEs depend on borrowing from banks, which leads to an increase in their costs.

\section{POLITICAL PROBLEMS}

The biggest problem facing MSMEs from 2015 until now is the political situation represented by the grinding war that ravaged Yemen until this point. Yemen is the poorest Arab country and has an unstable political situation; it faced political disorder since its union in 1990; due to its strong tribal social structure and geographic isolation, it has been difficult to govern centrally (Sharp, 2010). since 2011 when the people go to street the change the government, which leads to the current chaos and weak situation it escalated to the current conflict which leads to violence which started in 2014 and resulted in devising the country into two splits with two governing authorities while only one has a legitimate recognition (World Bank, 2019). The rapid business survey conducted to know the impact of the crisis on the private sector in Yemen by the UNDB and SMPS show that the most affected sector by war was the small and medium enterprises which 34\% of medium enterprises closing in the during of this situation compared to $17 \%$ of large businesses.MSMEs in the services sector was the most affected sector, which $35 \%$ of them closing. Also, the report shows that the most physical harm was to Aden nad Taiz, which affects $95 \%$ of all businesses, but most of these damages were partial; on the other hand, the impact of war on businesses in Sa'dah was more intense with higher incidences of complete damages recorded (43\%).

\section{FINANCING MSMEs}

The scarcity of capital has been one of the most problems facing MSMEs in Yemen are the difficulties of getting funds due to their size (lack of guarantees) and their novelty (lack of credit record). Therefore, financing institutions are exposed to several risks when financing MSMEs in their various stages of growth. (Establishment - initial - initial growth - actual growth - integration) because of these risks, commercial banks avoid providing the necessary financing for these projects due to their keenness on depositors' cash. So, the most challenge facing MSMEs in Yemen is to access financial institutions to get funds. However, Yemen's banking sector is still young and doesn't have enough experience working with MSMEs. Its role in financing MSMEs is still traditional and did not expand in serving all segments of society. Because the MSMEs try to get finance from a different source, which could be loans from family or friends. But now, most of the entrepreneurs, which could be the owners of MSMEs, try to get funds from microfinance institutions that provide microcredit to them with reasonable requirements. The microfinance institutions become an important tool to support MSMEs enable them to solve the problem of capital scarcity to see growth.

\subsection{POOR INFRASTRUCTURE}

Other challenges facing MSMEs in Yemen and according to the Baseline Survey of Micro and Small Enterprises in Yemen (MSE Survey), the Lack of infrastructure is rated third in the sequence of the problems that facing MSMEs.A country like Yemen, which has a poor Infrastructure and many areas in the country are difficult to access by road, roads are not always well maintained, and after the conflict in 2015, the roads became unsafe to travel, which in turn posed a great challenge to MSMEs.also, electricity cuts since the beginning of the conflict were a very big problem for the business sector as a whole in Yemen, not just the MSMEs sector due to that every MSME has to have its own electricity backup system or solar energy to keep running. Another problem facing MSMEs under Infrastructure is that the supply of water is available through the public network to around $40 \%$ of Yemen's population. The supply is not constant, so water is usually bought and delivered and stored in special containers to the business premises. Only in some areas of the country are sewage networks available. The extra costs borne by MSMEs stem from inadequate infrastructure. They need to handle stuff like securing water and maintaining power generators in addition to the financial costs, an additional burden on already weak management systems.

\section{THE ABSENCE OF SECURITY}

International Journal of Research -GRANTHAALAYAH 
absence of security and the rule of law were among the most challenges facing the growth of MSMEs in Yemen that because lawlessness in the country since 2011 which put the country in crisis-affected on the economy which is now shattered, and also the business is damaged, affected, or in loss (SEMC, 2016) In synchronism with the crisis that began in 2014, the rate of crime has been increased. Crimes like theft and fraud were the most problems facing MSMEs in these aspects due to the lawlessness status resulted from the fragile political situation. In some parts of Yemen, the crime rate increased to 60\% during the conflict time 2014-2019.

\section{LICENSING AND THE ABSENCE OF A SPECIFIC SMES AUTHORITY}

License and register MSMEs could be a challenge for the owner of MSMEs because there is no particular authority for MSMEs in Yemen, which contributed to the lack of support for MSMEs.However, there is a department in the Ministry of Industry and Trade (MOIT) called The General Administration of small Industries dedicated to supervising the small industrial enterprises, according to which the enterprises were defined in 2009 through a regulation based on the number of employees and the capital as well(Al-Attas, 2017). But there is some organization working to help small and medium-sized enterprises, such as the Social Fund for Growth (SFD), an organization that offers assistance to small enterprises. It was founded in 1997 with the help of the international community, in particular the World Bank. In 2005, SFD founded the Small and Micro Enterprise Service (SMEPS) as a subsidiary focusing on development projects aimed at creating more jobs by pursuing innovative strategies for the development of small enterprises, better responding to the conflict affecting small and medium-sized enterprises, by providing interventions to promote and create technical and economic capacity to revive the sm sector (World Bank, 2012; SMEPS, 2016; Ghanem, 2018).

\subsection{CORRUPTION}

Yemen is considered as one of the most countries in the world in terms of corruption indicators, as the Global Corruption Perceptions Index prepared by Transparency International confirmed that Corruption in public funds in Yemen during the year 2018 increased in Yemen from the year 2017 and Its ranked as177 among the most corrupt countries in the world in 2019 (Corruption Perceptions Index CPI). And Corruption is considered one of the most common problems that affect MSMEs (Gbetnkom, 2012). Corruption is a complicated and broad term that may be through receiving informal money to complete work (bribery), and administrative leakage also could be classified under Corruption. A feature of Corruption in the least developed countries, where facilitation payments or bribery are used to resolve or strengthen bureaucratic and administrative activities, which becomes a significant impediment to investment (Rune, 2011). Also, mediation between relatives to facilitate transactions is part of Corruption. Since the political crisis that hit Yemen and led Until the war began in 2015, corruption rates increased dramatically due to the absence of the government's role and the absence of oversight and accountability authorities, which caused high corruption rates in the last years.

Table 2: Corruption rate in Yemen

\begin{tabular}{|c|c|c|c|c|c|c|}
\hline Year & 2014 & 2015 & 2016 & 2017 & 2018 & 2019 \\
\hline Rank & 161 & 154 & 170 & 175 & 176 & 177 \\
\hline
\end{tabular}

Source: Corruption Perceptions Index

\subsection{RAW MATERIALS}

The difficulty in obtaining raw materials comes from the dependence of these projects on imported raw materials and local ones because they produced commodities that are substitutes for imported goods. This problem becomes clear when the crisis started, and the borders were closing in 2015, which lead to raising the prices of imports, so it is difficult for these projects to obtain large quantities.

\subsection{SKILLED EMPLOYEES}


The human element is considered one of the essential factors of production. Therefore, the shortage of skilled employees is one of the most critical obstacles facing the MSMEs, as it cannot be easily overcome even though its owners manage it in most cases. The lack of skilled employees is due to the workers' preference for work in large projects and government projects due to the presence of some benefits such as retirement, social security, and health. Also, because of the current crisis, many skilled employees preferred to work outside Yemen and leave the country due to the tremendous economic problems facing Yemen.

\section{CONCLUSION}

Micro, Small, Medium enterprises MSMEs have great importance in any country's economy, whether developing or developed, and its importance lies in reducing unemployment rates and innovation and contributing to raising the GDP. Therefore, many countries seek attention and development of this sector in many aspects, whether financial or non-financial, by providing them appropriate funds to start the business and by issuing laws regulating its work and reducing tax rates for them. From the above, it becomes clear the importance of MSMEs. On the other hand, when the world focuses on developing the small enterprise sector, the MSMEs sector in Yemen function in a harsh business environment as one of the least developing countries and a more challenging environment in light of the current polio-economic unrest and instability. The challenges and difficulties became more affecting MSMEs' performance after the political crisis, which started in 2011, and the conflict from 2015 until now.

\section{SOURCES OF FUNDING}

This research received no specific grant from any funding agency in the public, commercial, or not-for-profit sectors.

\section{CONFLICT OF INTEREST}

The author have declared that no competing interests exist.

\section{ACKNOWLEDGMENT}

None.

\section{REFERENCES}

[1] <a href='https://www.macrotrends.net/countries/YEM/yemen/gdp-growth-rate'>Yemen GDP Growth Rate 1991-2020</a>. www.macrotrends.net. Retrieved 2020-11-29.

[2] Abdullah, A., Thomas, B., \& Metcalfe, S. (2015). Measuring the E-Business activities of SMEs in Yemen. Small, 10(49), 4-9.

[3] Al Hawat, Ali. (2007) Small size Youth Projects and the integration of the Job market, Libya experience, A National forum on small and medium-size projects as a choice for reducing unemployment and a future for youth Arab countries, Tunis

[4] Al-Absi, A. A. (2016). Impact of microcredit in microfinance banks on small business spread in Yemen (Case study of Sana'a, Yemen). International Journal of Business and Management Invention, 5(11), 14-29. Retrieved from www.ijbmi.org.

[5] Alattar, J., Kouly, R. and Innes, J., (2009), "Management accounting information in micro enterprise in Gaza", Journal of Accounting and Organizational Change, Vol. 5, No. 1, pp. 81-107.

[6] Al-Attas, W. A. S. (2017). Strategic analysis in small and medium enterprises in Yemen, Recherches économiques et managériales, Vol. 21, p. 211-234 http://revues.univbiskra.dz/index.php/rem/article/view/3845

[7] Al-Beltagy (2005), Dr. Mohamed El-Beltagy, Director of Sharia-compliant Banking Programs, Banking Institute, Saudi Arabian Monetary Agency (SAMA), "Proposed Formulas for Microfinance and Accounting Treatment of the Participation Formula". 
[8] Alhammadi, A., \& Shahadan, F. (2014). The determinants of growth performance of small services enterprises in Yemen. Journal Economic Malaysia, 48(1), 35-48.

[9] Alshebami, A. S. (2017). The Role of Microfinance in Mitigating Poverty and Unemployment in yemen. SRTM University, India-Nanded.

[10] Alshebami, A. S. (2017). The Role of Microfinance in Mitigating Poverty and Unemployment in yemen. SRTM University, India-Nanded.

[11] Alshebami, A. S., \& Khandare, D. M. (2014). Microfinance in Yemen "Challenges and Opportunities ". A Monthly Double-Blind Peer Reviewed Refereed Open Access International e-Journal-Included in the International Serial Directories International

[12] Alshebami, A. S., \& Khandare, D. M. (2014). Microfinance in Yemen "Challenges and Opportunities ". A Monthly Double-Blind Peer Reviewed Refereed Open Access International e-Journal-Included in the International Serial Directories International Journal in Management and Social Science, 2(12). Retrieved from http://www.ijmr.net.in

[13] Alshebami, A. S., \& Khandare, D. M. (2015). The Impact of Interest Rate Ceilings on Microfinance Industry. International Journal of Social Work, 2(2), 10. https://doi.org/10.5296/ijsw.v2i2.7953

[14] Alshebami, A. S., Sami A. Morsi, Muhammad Raza, \& Atif Aziz. (2020). Exploring the Potential Of Microinsurance For Challenging The Vulnerabilities In Poverty Sector Of Yemen (An Empirical Study From Demand Side Perspectives). International Journal of Disaster and Business Continuity, 11(1), 1288-1302

[15] Avevor, E.2016.Challenges faced by SMEs when accessing fund from financial institutions available in https://www.theseus.fi/bitstream/handle/10024/108217/FINAL\%20THE-

SIS\%20Eric\%20nka\%20COMMENT-1.pdf?sequence=1. Accessed on 12.08.2018.

[16] Brown, D (1990). Global perspective perceptions of SME growth constraints in Nigeria Journal of Small Business Management, 40 (1), 58-65

[17] Gebru, G. H. (2009). Financing preferences of micro and small entreprise owners in Tigray: does POH hold?. Journal of Small Business and Enterprise Development, 16,322-334.

[18] Ghanem, M. (2018). The Small and Micro Enterprise Service (SMEPS): Bridging the Void, retrieved from:https://almadaniyamag.com/2018/05/22/2018-5-22-the-small-and-micro-enterprise-service-

bridging-the-void/ (Accessed: 31/8/2019)

[19] Gichuki, J. A. W., Njeru, A., \& Tirimba, O. I. (2014). Challenges facing micro and small enterprises in accessing credit facilities in Kangemi Harambee market in Nairobi City County, Kenya. International Journal of Scientific and Research Publications, 4(12), 1-25. https://doi.org/10.5296/ijsw.v2i2.7953

[20] Ilahi, S. Micro, Small and Medium Enterprises (MSMEs) in Delhi: Problems and Prospects.

[21] International Monetary Fund, World Economic Outlook October 2019.

[22] Levy, B. (1993). Obstacles to developing indigenous small and medium enterprises: An empirical assessment. The World Bank Economic Review, Oxford University Press, 7(1) (Jan., 1993). 65-83

[23] liriani, K. (2013). Role of SMEs in the Economy: The Case of Yemen, proceeding of: Yemen: Challenges forthe Future, International Conference, London, January 11\&12, 2013.

[24] Lybaert, N. (1998). The information use in a SME: its importance and some elements of influence. Small Business Economics, 10(2), 171-191.

[25] Mandal, T. (2007). Small and Medium enterprises in BIMSTEC: Synergies and Emerging issues for cooperation. Center for studies in International relations and development (CSIRD). Kolkata.

[26] MSE Baseline Survey. (2000). Social Fund for Development. Yemen.

[27] O’Dwyer, M., \& Ryan, E. (2000). Management development issues for owners/managers of micro-enterprises. Journal of European Industrial Training.

[28] Osama Mohammed Elhassan. Obstacles and Problems Facing the Financing of Small and Medium Enterprises in KSA. Journal of Finance and Accounting. Vol. 7, No. 5, 2019, pp. 168-183. doi: 10.11648/j.jfa.20190705.16

[29] Peci, F., Kutllovci, E., Tmava, Q., \& Shala, V. (2012). Small and medium enterprises facing institutional barriers in Kosovo. International Journal of Marketing Studies, 4(1), 95.

[30] Prasad, S., \& Tata, J. (2009). Micro-enterprise quality. International Journal of Quality \& Reliability Management,26(3), 234-246.

[31] Qandah, A, (2009), Monetary and Financial Policies and Their Impact on Retail Lending and SME Financing. Jordan: Association of Banks. 
[32] Raza, M., Manurung, D. T. H., \& Alshebami, A. (2020). Impact of education and training on performance of women entrepreneurs in Indonesia: Moderating effect of personal characteristics. Management Science Letter, (August). https://doi.org/10.5267/j.msl.2020.7.018

[33] Rune, A. (2011). Corruption and SMEs: Exploring the business case for western SMEs to counter involvement in administrative corruption in developing countries. Copenhagen Business School, Business and Development Studies, CBS.

[34] Saleh, M. A. K., \& Manjunath, K. R. (2020). Review of Historical and Temporary Challenges Facing Small and Medium Enterprises in Yemen. International Journal of Trend in Scientific Research and Development, 4(3), 752-764.6

[35] Sharp, J. M. (2010). Yemen: Background and U.S. relations. DIANE Publishing.

[36] Small enterprises tend to be as a primary source of job or employment creation worldwide; not only, in lessdeveloped countries (LDCs) such as Yemen, but also in developed countries as well. However, (Alhammadi \& Shahadan, 2014).

[37] Tambunan, T. (2006). Micro, Small, and Medium Enterprises and Economic Growth. Working paper series No. 14. Center for Industry and SME Studies. Faculty of Economics, University of Trisakti

[38] World Bank. 2019. The World Bank Annual Report 2019: Ending Poverty, Investing in Opportunity. Washington, DC: World Bank. (C) World Bank. https://openknowledge.worldbank.org/handle/10986/32333 License: CC BY-NC-ND 3.0 IGO."

[39] YMIT .2014. General report of the result of the comprehensive industrial survey 2010. Yemen Ministry of trade and industry. 